\title{
Characterization of the genetic diversity in Passiflora spp. in the Boyacá Department, Colombia
}

\author{
María A. Martínez ${ }^{1}$, Ana C. Morillo ${ }^{2 *}$, and Wendy Reyes-Ardila ${ }^{2}$ \\ ${ }^{1}$ Universidad Pedagógica y Tecnológica de Colombia, Facultad de Ciencias Básicas, Avenida Central Norte 39-115, Tunja, Colombia. \\ ${ }^{2}$ Universidad Pedagógica y Tecnológica de Colombia, Facultad de Ciencias Agropecuarias, Avenida Central Norte 39-115, Tunja, \\ Colombia. "Corresponding author (ana.morillo@uptc.edu.co).
}

Received: 3 January 2020; Accepted: 30 March 2020; doi:10.4067/S0718-58392020000300342

\begin{abstract}
Passiflora is a group of species of economic importance in Colombia because of their productive potential and nutritional, pharmaceutical and industrial properties; therefore, it is necessary to study the genetic diversity of the species cultivated in principal productive departments, such as Boyacá. The use of molecular markers has become a fundamental tool for germplasm characterization, which effectively complements morphological and agronomic information. This research aimed to characterize the genetic diversity of Passiflora spp. grown in the Department of Boyacá using inter-simple sequence repeat (ISSR) markers. The eight ISSRs generated a total 138 bands with molecular weights between 250 and $1350 \mathrm{~kb}$. With a similarity coefficient of 0.60 , seven groups were formed, showing lax distribution of the individuals. The percentage of polymorphic loci was between 56\% (TG) and 90\% (AG). The average value of heterozygosity was 0.56 with a genetic differentiation coefficient (FST) of 0.16 , which indicated great genetic diversity but without a defined population structure. The AMOVA showed that $64 \%$ of the observed genetic variation was due to the component within the groups. The results suggested levels of hierarchy and subdivision finer than those considered in this study, in addition to a complementary morphoagronomic characterization that established the total genetic diversity, which can be used to implement a breeding program for more productive cultivars that are resistant to the principal phytosanitary problems.
\end{abstract}

Key words: Fruit trees, genetic diversity, microsatellites, variability.

\section{INTRODUCTION}

The Passiflora genus is the most representative one of the Passifloraceae family, with around 520 species distributed in the tropical regions of the Americas, Asia and Africa (Araya et al., 2017). Cultivated species have great nutritional, medicinal and ornamental value since they are a source of minerals, vitamins A, C and D, alkaloids, flavonoids and carotenoids, which are beneficial for human health. These species have compounds with anxiolytic, antihypertensive, sedative and analgesic properties (Konta et al., 2014). The seeds are a source of essential fatty acids that can be used in food and cosmetic industries (Malacrida and Neuza, 2012). In spite of the economic importance and various potential uses, studies on the characterization of the diversity of the germplasm of cultivated passionflower in Colombia, specifically in the Department of Boyacá, are limited.

Colombia is the center of diversity of an important group of these species. Passiflora edulis Sims f. flavicarpa O. Deg. known as passion fruit, P. edulis Sims f. edulis (gulupa), P. tripartita (Juss.) Poir. var. mollissima (Kunth) Holm-Niels. \& P. Jørg. (curuba), P. maliformis L. (cholupa), and P. ligularis Juss. (granadilla) have acquired economic importance because of their production and export potential. Passiflora production in the country increased $34 \%$ in the last $3 \mathrm{yr}$, reaching 227813 t during 2018, the principal production departments include Antioquia and Meta (Agronet, 2019). Boyacá has increased area and production for Passiflora; by 2018, it had a planted area of 1532 ha, with a yield of $10.5 \mathrm{t} \mathrm{ha}^{-1}$. Despite 
the productive potential, a limiting factor in the development of this crop in Colombia is the incidence of pests and diseases, generating significant losses in yield (Ocampo et al., 2013). On the other hand, there is a need for breeding programs that offer cultivars with higher genetic and phytosanitary quality that respond to the needs of farmers (Ocampo et al., 2017).

The genetic diversity in the Passiflora genus is very wide, both within the genus and within the most cultivated species (Vianna et al., 2019), so the characterization of the genetic variation is essential for the conservation, management and efficient use of germplasm in genetic breeding programs (Oluoch et al., 2018). Traditionally, diversity in Passiflora is estimated by observing variations in morphological or agronomic characteristics or tolerance to biotic or abiotic factors, which does not reflect the genetic relationship between evaluated materials and is affected by environmental changes and dependence on the stage of development (Pereira et al., 2015). DNA markers overcome these limitations and are a useful tool for the evaluation and characterization of germplasm (Vieira et al., 2019).

The genetic diversity in Passiflora has been studied with different molecular techniques, such as random amplified polymorphic DNA (RAPD), amplified fragment length polymorphism (AFLP), and sequence-related amplified polymorphism (SRAP) (Oluoch et al., 2018; Vieira et al., 2019); however, simple sequence repeat (SSR) markers are the most used techniques for the characterization of germplasm in different crops since they are highly polymorphic, reproducible and co-dominant, with wide genome coverage (Gramazio et al., 2018). Among the microsatellite markers, inter-simple sequence repeat (ISSR), which combines characteristics of the RAPD and microsatellites techniques, facilitates multilocus genomic analysis with a single primer based on regions of SSR, presents good reproducibility, has a low cost, is simple, does not need previous genome information (Morillo et al., 2018), and has proven to be polymorphic and informative in studies on genetic diversity in Passiflora (Santos et al., 2011; Sousa et al., 2015; Batista et al., 2017; Oliveira et al., 2019; Vianna et al., 2019).

In Colombia, genetic diversity studies conducted by Santos et al. (2011) with ISSR markers in P. edulis (purple and yellow type) and $P$. alata have shown that there is no structure in the evaluated populations; however, these studies provided information for genetic improvement. Other research conducted in Colombian on P. ligularis accessions (sweet granadilla) suggests that the cultivated germplasm has high variability $(\mathrm{He}=0.96)$, with a slight genetic structure (Bernal et al., 2014). Ocampo et al. (2017) studied the genetic diversity and population structure of 51 Colombian passion fruit accessions $(P$. edulis Sims f. flavicarpa O. Deg.) using microsatellite markers, where there was little geographic structuring and high differentiation between individuals of the same accession. Galeano et al. (2018) conducted an agronomic evaluation of 60 accessions of $P$. edulis Sims from the Agrosavia germplasm bank, where 30 promising accessions were identified; however, this information must be complemented with biochemical and molecular data. Fonseca-Trujillo et al. (2019) characterized cultivated gulupa materials (P. edulis f. edulis) collected in the Departments of Boyacá, Cundinamarca and Huila using ISSR markers, finding high genetic diversity, probably as a result of the method of propagation, provenance and short time of crop establishment. Studies of genetic diversity in the Passiflora spp. germplasm in the department of Boyacá are necessary for the sustainable use of its genetic resource with a view to increasing the profitability of the crop by identifying elite materials that have good yields, with tolerance to biotic and abiotic factors and adapted to local conditions.

In this context, it is necessary to continue with genetic studies in order to gather more information on the current genetic diversity of Passiflora and the relationships between individuals of the germplasm. For this reason, the objective of this research was to evaluate the genetic diversity in 71 cultivated Passiflora materials from the Department of Boyacá in order to provide the information for the management, conservation and efficient use of this plant genetic resource.

\section{MATERIALS AND METHODS}

\section{Plant material}

The sampling of the Passiflora spp. was carried out in the main producing municipalities in the Department of Boyacá (Firavitoba, Ramiriquí, Umbita, Turmeque, Sutamarchán, Tinjacá, Buenavista, Miraflores, Briceño, Tunungua and Nuevo Colón), in total 11 municipalities and 19 farms were sampled. In each of the municipalities, production farms with a tradition in cultivation were visited, where taking into account sanitary quality and phenotypic variation, four plants were selected at random per species. Table 1 shows the specific geographical location of the sampling points according to the species sampled and the selected plants. The identification of the species was made in situ according to the information provided by the farmers and was corroborated by the herbarium of the Universidad Pedagógica y Tecnológica de Colombia. 
Table 1. Collection sites for Passiflora spp. in the Department of Boyacá.

\begin{tabular}{|c|c|c|c|}
\hline $\mathrm{Nr}$ & Species & Municipality & Geographic coordinates \\
\hline 1 & Passiflora edulis f. edulis & Firabitoba & $5^{\circ} 40^{\prime} 08^{\prime \prime} \mathrm{N}, 72^{\circ} 59^{\prime} 38^{\prime \prime} \mathrm{W}$ \\
\hline 2 & P. edulis f. edulis & Firabitoba & $5^{\circ} 40^{\prime} 08^{\prime \prime} \mathrm{N}, 72^{\circ} 59^{\prime} 38^{\prime \prime} \mathrm{W}$ \\
\hline 3 & P. edulis f. edulis & Firabitoba & $5^{\circ} 40^{\prime} 08^{\prime \prime} \mathrm{N}, 72^{\circ} 59^{\prime} 38^{\prime \prime} \mathrm{W}$ \\
\hline 4 & P. edulis f. edulis & Ramiriquí & $5^{\circ} 25^{\prime} 1^{\prime \prime} \mathrm{N}, 73^{\circ} 19^{\prime} 59^{\prime \prime} \mathrm{W}$ \\
\hline 5 & P. edulis f. edulis & Ramiriquí & $5^{\circ} 25^{\prime} 1^{\prime \prime} \mathrm{N}, 73^{\circ} 19^{\prime} 59^{\prime \prime} \mathrm{W}$ \\
\hline 6 & P. edulis f. edulis & Ramiriquí & $5^{\circ} 25^{\prime} 1^{\prime \prime} \mathrm{N}, 73^{\circ} 19^{\prime} 59^{\prime \prime} \mathrm{W}$ \\
\hline 7 & P. edulis f. edulis & Ramiriquí & $5^{\circ} 25^{\prime} 1^{\prime \prime} \mathrm{N}, 73^{\circ} 19^{\prime} 59^{\prime \prime} \mathrm{W}$ \\
\hline 8 & P. edulis f. edulis & Ramiriquí & $5^{\circ} 25^{\prime} 1^{\prime \prime} \mathrm{N}, 73^{\circ} 19^{\prime} 59^{\prime \prime} \mathrm{W}$ \\
\hline 9 & P. edulis f. edulis & Ramiriquí & $5^{\circ} 25^{\prime} 1{ }^{\prime \prime} \mathrm{N}, 73^{\circ} 19^{\prime} 59^{\prime \prime} \mathrm{W}$ \\
\hline 10 & P. edulis f. edulis & Ramiriquí & $5^{\circ} 25^{\prime} 1^{\prime \prime} \mathrm{N}, 73^{\circ} 19^{\prime} 59^{\prime \prime} \mathrm{W}$ \\
\hline 11 & P. edulis f. edulis & Ramiriquí & $5^{\circ} 25^{\prime} 1^{\prime \prime} \mathrm{N}, 73^{\circ} 19^{\prime} 59^{\prime \prime} \mathrm{W}$ \\
\hline 12 & P. edulis f. edulis & Ramiriquí & $5^{\circ} 25^{\prime} 1^{\prime \prime} \mathrm{N}, 73^{\circ} 19^{\prime} 59^{\prime \prime} \mathrm{W}$ \\
\hline 13 & P. edulis f. edulis & Ramiriquí & $5^{\circ} 25^{\prime} 1^{\prime \prime} \mathrm{N}, 73^{\circ} 19^{\prime} 59^{\prime \prime} \mathrm{W}$ \\
\hline 14 & P. edulis f. edulis & Ramiriquí & $5^{\circ} 25^{\prime} 1^{\prime \prime} \mathrm{N}, 73^{\circ} 19^{\prime} 59^{\prime \prime} \mathrm{W}$ \\
\hline 15 & P. ligularis & Ramiriquí & $5^{\circ} 25^{\prime} 1^{\prime \prime} \mathrm{N}, 73^{\circ} 19^{\prime} 59^{\prime \prime} \mathrm{W}$ \\
\hline 16 & P. ligularis & Ramiriquí & $5^{\circ} 25^{\prime} 1^{\prime \prime} \mathrm{N}, 73^{\circ} 19^{\prime} 59^{\prime \prime} \mathrm{W}$ \\
\hline 17 & P. maliformis red flower & Umbita & $5^{\circ} 13^{\prime} 1 " \mathrm{~N}, 73^{\circ} 28^{\prime} 1^{\prime \prime} \mathrm{W}$ \\
\hline 18 & P. maliformis red flower & Umbita & $5^{\circ} 13^{\prime} 1{ }^{\prime \prime} \mathrm{N}, 73^{\circ} 28^{\prime} 1^{\prime \prime} \mathrm{W}$ \\
\hline 19 & P. maliformis white flower & Umbita & $5^{\circ} 13^{\prime} 1^{\prime \prime} \mathrm{N}, 73^{\circ} 28^{\prime} 1^{\prime \prime} \mathrm{W}$ \\
\hline 20 & P. maliformis red flower & Umbita & $5^{\circ} 13^{\prime} 1 " \mathrm{~N}, 73^{\circ} 28^{\prime} 1{ }^{\prime \prime} \mathrm{W}$ \\
\hline 21 & P. maliformis red flower & Turmeque & $5^{\circ} 19^{\prime} 20^{\prime \prime} \mathrm{N}, 73^{\circ} 29^{\prime} 21^{\prime \prime} \mathrm{W}$ \\
\hline 22 & P. maliformis red flower & Turmeque & $5^{\circ} 19^{\prime} 20^{\prime \prime} \mathrm{N}, 73^{\circ} 29^{\prime} 21^{\prime \prime} \mathrm{W}$ \\
\hline 23 & P. maliformis red flower & Turmeque & $5^{\circ} 19^{\prime} 20^{\prime \prime} \mathrm{N}, 73^{\circ} 29^{\prime} 21^{\prime \prime} \mathrm{W}$ \\
\hline 24 & P. maliformis white flower & Turmeque & $5^{\circ} 19^{\prime} 20^{\prime \prime} \mathrm{N}, 73^{\circ} 29^{\prime} 21^{\prime \prime} \mathrm{W}$ \\
\hline 25 & P. ligularis & Turmeque & $5^{\circ} 19^{\prime} 20^{\prime \prime} \mathrm{N}, 73^{\circ} 29^{\prime} 21^{\prime \prime} \mathrm{W}$ \\
\hline 26 & P. ligularis & Turmeque & $5^{\circ} 19^{\prime} 20^{\prime \prime} \mathrm{N}, 73^{\circ} 29^{\prime} 21^{\prime \prime} \mathrm{W}$ \\
\hline 27 & P. tripartita var. mollisima common pink & Turmeque & $5^{\circ} 19^{\prime} 20^{\prime \prime} \mathrm{N}, 73^{\circ} 29^{\prime} 21^{\prime \prime} \mathrm{W}$ \\
\hline 28 & P. tripartita var. mollisima common & Turmeque & $5^{\circ} 19^{\prime} 20^{\prime \prime} \mathrm{N}, 73^{\circ} 29^{\prime} 21^{\prime \prime} \mathrm{W}$ \\
\hline 29 & P.edulis f.edulis & Sutamarchán & $5^{\circ} 38^{\prime} 3 " \mathrm{~N}, 73^{\circ} 37^{\prime} 12^{\prime \prime} \mathrm{W}$ \\
\hline 30 & P. edulis f. edulis & Sutamarchán & $5^{\circ} 38^{\prime} 3 ” \mathrm{~N}, 73^{\circ} 37^{\prime} 12^{\prime \prime} \mathrm{W}$ \\
\hline 31 & P. edulis f. edulis & Sutamarchán & $5^{\circ} 38^{\prime} 3 ” \mathrm{~N}, 73^{\circ} 37^{\prime} 12^{\prime \prime} \mathrm{W}$ \\
\hline 32 & P. tripartita var. mollisima common pink & Sutamarchán & $5^{\circ} 38^{\prime} 3 ” \mathrm{~N}, 73^{\circ} 37^{\prime} 12^{\prime \prime} \mathrm{W}$ \\
\hline 33 & P. tripartita var. mollisima common pink & Sutamarchán & $5^{\circ} 38^{\prime} 3 ” \mathrm{~N}, 73^{\circ} 37^{\prime} 12^{\prime} \mathrm{W}$ \\
\hline 34 & P. tripartita var. mollisima common pink & Sutamarchán & $5^{\circ} 38^{\prime} 3 ” \mathrm{~N}, 73^{\circ} 37^{\prime} 12^{\prime \prime} \mathrm{W}$ \\
\hline 35 & Graft P. maliformis (cholupa)-P. edulis f. edulis (gulupa) & Tinjacá & $5^{\circ} 34^{\prime} 54^{\prime \prime} \mathrm{N}, 74^{\circ} 38^{\prime} 53^{\prime \prime} \mathrm{W}$ \\
\hline 36 & Graft P. maliformis (cholupa)-P. edulis f. edulis (gulupa) & Tinjacá & $5^{\circ} 34^{\prime} 54^{\prime}{ }^{\prime} \mathrm{N}, 74^{\circ} 38^{\prime} 53^{\prime \prime} \mathrm{W}$ \\
\hline 37 & Graft P. maliformis (cholupa)-P. edulis f. edulis (gulupa) & Tinjacá & $5^{\circ} 34^{\prime} 54^{\prime \prime} \mathrm{N}, 74^{\circ} 38^{\prime} 53^{\prime \prime} \mathrm{W}$ \\
\hline 38 & Graft congolo-cholupa & Tinjacá & $5^{\circ} 34^{\prime} 54^{\prime \prime} \mathrm{N}, 74^{\circ} 38^{\prime} 53^{\prime \prime} \mathrm{W}$ \\
\hline 39 & P. edulis f. edulis & Tinjacá & $5^{\circ} 34^{\prime} 54^{\prime \prime} \mathrm{N}, 74^{\circ} 38^{\prime} 53^{\prime \prime} \mathrm{W}$ \\
\hline 40 & P. ligularis & Tinjacá & $5^{\circ} 34^{\prime} 54^{\prime \prime} \mathrm{N}, 74^{\circ} 38^{\prime} 53^{\prime \prime} \mathrm{W}$ \\
\hline 41 & P. edulis f. edulis & Buenavista & $5^{\circ} 30^{\prime} 60^{\prime \prime} \mathrm{N}, 73^{\circ} 57^{\prime} 59^{\prime \prime} \mathrm{W}$ \\
\hline 42 & P. edulis f. edulis & Buenavista & $5^{\circ} 30^{\prime} 60^{\prime \prime} \mathrm{N}, 73^{\circ} 57^{\prime} 59^{\prime \prime} \mathrm{W}$ \\
\hline 43 & P. edulis f. edulis & Buenavista & $5^{\circ} 30^{\prime} 60^{\prime \prime} \mathrm{N}, 73^{\circ} 57^{\prime} 59^{\prime \prime} \mathrm{W}$ \\
\hline 44 & P. edulis f. flavicarpa & Miraflores & $5^{\circ} 13^{\prime} 1^{\prime \prime} \mathrm{N}, 73^{\circ} 87^{\prime} 7^{\prime} \mathrm{W}$ \\
\hline 45 & P. edulis f. flavicarpa & Miraflores & $5^{\circ} 13^{\prime} 1 " \mathrm{~N}, 73^{\circ} 8^{\prime} 47^{\prime \prime} \mathrm{W}$ \\
\hline 46 & P. edulis f. flavicarpa & Miraflores & $5^{\circ} 13^{\prime} 1^{\prime \prime} \mathrm{N}, 73^{\circ} 8^{\prime} 47^{\prime \prime} \mathrm{W}$ \\
\hline 47 & P. edulis f. flavicarpa & Miraflores & $5^{\circ} 13^{\prime} 1^{\prime \prime} \mathrm{N}, 73^{\circ} 8^{\prime} 47^{\prime \prime} \mathrm{W}$ \\
\hline 48 & P. edulis f. flavicarpa & Miraflores & $5^{\circ} 13^{\prime} 1{ }^{\prime \prime} \mathrm{N}, 73^{\circ} 8^{\prime} 47^{\prime \prime} \mathrm{W}$ \\
\hline 49 & P. edulis f. flavicarpa & Miraflores & $5^{\circ} 13^{\prime} 1 " \mathrm{~N}, 73^{\circ} 8^{\prime} 47^{\prime \prime} \mathrm{W}$ \\
\hline 50 & P. edulis f. edulis & Miraflores & $5^{\circ} 13^{\prime} 1^{\prime \prime} \mathrm{N}, 73^{\circ} 8^{\prime} 47^{\prime \prime} \mathrm{W}$ \\
\hline 51 & P. edulis f. edulis & Miraflores & $5^{\circ} 13^{\prime} 1^{\prime \prime} \mathrm{N}, 73^{\circ} 8^{\prime} 47^{\prime \prime} \mathrm{W}$ \\
\hline 52 & P. edulis f. edulis & Miraflores & $5^{\circ} 13^{\prime} 1^{\prime \prime} \mathrm{N}, 73^{\circ} 8^{\prime} 47^{\prime \prime} \mathrm{W}$ \\
\hline 53 & Graft congolo-cholupa & Miraflores & $5^{\circ} 13^{\prime} 1 " \mathrm{~N}, 73^{\circ} 8^{\prime} 47^{\prime \prime} \mathrm{W}$ \\
\hline 54 & Graft congolo-cholupa & Miraflores & $5^{\circ} 13^{\prime} 1{ }^{\prime \prime} \mathrm{N}, 73^{\circ} 8^{\prime} 47^{\prime \prime} \mathrm{W}$ \\
\hline 55 & Graft congolo-cholupa & Miraflores & $5^{\circ} 13^{\prime} 1^{\prime \prime} \mathrm{N}, 73^{\circ} 8^{\prime} 47^{\prime \prime} \mathrm{W}$ \\
\hline 56 & P. edulis f. flavicarpa purple fruit & Miraflores & $5^{\circ} 13^{\prime} 1 ” \mathrm{~N}, 73^{\circ} 8^{\prime} 47^{\prime \prime} \mathrm{W}$ \\
\hline 57 & P. edulis f. flavicarpa & Miraflores & $5^{\circ} 13^{\prime} 1{ }^{\prime \prime} \mathrm{N}, 73^{\circ} 8^{\prime} 47^{\prime \prime} \mathrm{W}$ \\
\hline 58 & P. edulis f. flavicarpa & Miraflores & $5^{\circ} 13^{\prime} 1^{\prime \prime} \mathrm{N}, 73^{\circ} 8^{\prime} 47^{\prime \prime} \mathrm{W}$ \\
\hline 59 & P. edulis f. flavicarpa & Miraflores & $5^{\circ} 13^{\prime} 1^{\prime \prime} \mathrm{N}, 73^{\circ} 8^{\prime} 47^{\prime \prime} \mathrm{W}$ \\
\hline 60 & P. edulis f. flavicarpa & Miraflores & $5^{\circ} 13^{\prime} 1^{\prime \prime} \mathrm{N}, 73^{\circ} 8^{\prime} 47^{\prime \prime} \mathrm{W}$ \\
\hline 61 & P. edulis f. flavicarpa & Briceño & $5^{\circ} 43^{\prime} 25^{\prime \prime} \mathrm{N}, 73^{\circ} 56^{\prime} 24^{\prime \prime} \mathrm{W}$ \\
\hline
\end{tabular}


Continuation Table 1.

\begin{tabular}{llcc}
\hline $\mathrm{Nr}$ & Species & Municipality & Geographic coordinates \\
\hline 62 & P.edulis f. flavicarpa & Briceño & $5^{\circ} 43^{\prime} 25^{\prime \prime} \mathrm{N}, 73^{\circ} 56^{\prime} 24^{\prime \prime} \mathrm{W}$ \\
63 & P. edulis f. flavicarpa & Briceño & $5^{\circ} 43^{\prime} 25^{\prime \prime} \mathrm{N}, 73^{\circ} 56^{\prime} 24^{\prime \prime} \mathrm{W}$ \\
64 & P. edulis f. flavicarpa & Tunungua & $5^{\circ} 43^{\prime} 59^{\prime \prime} \mathrm{N}, 73^{\circ} 55^{\prime} 59^{\prime \prime} \mathrm{W}$ \\
65 & P. edulis f. flavicarpa & Tunungua & $5^{\circ} 433^{\prime} 59^{\prime \prime} \mathrm{N}, 73^{\circ} 55^{\prime} 59^{\prime \prime} \mathrm{W}$ \\
66 & P. edulis f. flavicarpa & Tunungua & $5^{\circ} 433^{\prime} 59^{\prime \prime} \mathrm{N}, 73^{\circ} 55^{\prime} 59^{\prime \prime} \mathrm{W}$ \\
67 & P.edulis f. flavicarpa purple fruit & Tunungua & $5^{\circ} 433^{\prime} 59^{\prime \prime} \mathrm{N}, 73^{\circ} 55^{\prime} 59^{\prime \prime} \mathrm{W}$ \\
68 & Graft congolo-cholupa & Nuevo Colón & $5^{\circ} 21^{\prime} 30^{\prime \prime} \mathrm{N}, 73^{\circ} 27^{\prime} 38^{\prime \prime} \mathrm{W}$ \\
69 & Graft congolo-cholupa & Nuevo Colón & $5^{\circ} 21^{\prime} 30^{\prime \prime} \mathrm{N}, 73^{\circ} 27^{\prime} 38^{\prime \prime} \mathrm{W}$ \\
70 & Congolo in vitro & Nuevo Colón & $5^{\circ} 21^{\prime} 30^{\prime \prime} \mathrm{N}, 73^{\circ} 27^{\prime} 38^{\prime \prime} \mathrm{W}$ \\
\hline
\end{tabular}

\section{Molecular characterization}

The molecular characterization was carried out in the Molecular Biology research laboratories of the Universidad Pedagógica y Tecnológica de Colombia (UPTC), Tunja. The protocol of Dellaporta et al. (1983) was used for the DNA extraction, which was visualized in $0.8 \%$ agarose gels prepared with $0.5 \%$ TBE in an electrophoresis gel system (EC 340, Maxicell Primo, Thermo Fisher Scientific, Waltham, Massachusetts, USA). The concentration was determined with a fluorometer (Dyna Quant 200, Hoefer, Holliston, Massachusetts, USA), diluted in HPLC water to a total volume of $100 \mathrm{~mL}$ at $10 \mathrm{ng}$ $\mathrm{mL}^{-1}$ and stored at $-20{ }^{\circ} \mathrm{C}$. For the ISSR analysis, eight primers synthesized by Technologies Inc. Bioneer Corporation (Alameda, California, USA) were selected (Table 2 ) because they are highly polymorphic and efficient in determining intra and interspecific genetic diversity in genetic diversity in plants like Passiflora spp. (Oliveira et al., 2019; Vianna et al., 2019).

For the amplification, the cocktail was prepared in a sterile microcentrifuge tube $(1.5 \mathrm{~mL})$ for a final volume of $25 \mu \mathrm{L}$. Reaction components are indicated as final concentration. The reaction mixture was prepared with $1 \mathrm{X}$ buffer, $1.5 \mathrm{mM}$ $\mathrm{MgCl}_{2}, 0.2 \mathrm{mM}$ dNTPs, $1 \mathrm{U}$ Taq Polymerase, $2 \mu \mathrm{M}$ primer and $10 \mathrm{ng}$ genomic DNA. The amplification was carried out in a programmable thermal controller thermal cycler (PTC-100, MJ Research, St. Bruno, Canada). The initial denaturation was $95^{\circ} \mathrm{C}$ for $5 \mathrm{~min} ; 37$ cycles of denaturation at $95^{\circ} \mathrm{C}$ for $30 \mathrm{~s}$, and hybridization: $58^{\circ} \mathrm{C}$ (GT, CGA), $50{ }^{\circ} \mathrm{C}(\mathrm{AG}, \mathrm{CA}$, $\mathrm{ACA}$ ), and $55^{\circ} \mathrm{C}$ (CCA, TG, CT) for $45 \mathrm{~s}$, with an extension of $72{ }^{\circ} \mathrm{C}$ for $2 \mathrm{~min}$. The final extension was at $72{ }^{\circ} \mathrm{C}$ for 7 min. The amplification products were separated using electrophoresis in $3 \%$ high resolution agarose gels prepared with $1 \% \mathrm{TBE}$, at $100 \mathrm{~V}$ for $3 \mathrm{~h}$ and displayed on a transilluminator.

\section{Statistical data analysis}

A binary matrix of presence (1) and absence (0) was generated. The genetic similarity between the evaluated materials was calculated with the coefficient of Nei and Li (1979). Clustering analysis was performed using the UPGMA method, and a dendrogram was generated using the NTSYS statistical package (Numerical Taxonomy System for Personal Computer, version 2.02 PC, Setauket, New York, USA). The parameters of genetic diversity were estimated with the TFPGA program (Tools for Population Genetic Analysis, version 1.3, 1997, Miller, Northern Arizona University, Flagstaff, Arizona, USA), where the percentage of polymorphic loci and the heterozygosity were unbiased. The unbiased statistical "F" value was determined with a 95\% confidence interval. The molecular variance analysis (AMOVA, Excoffier, Rutgers University, New Jersey, USA) was done with the GenAlEx 6.5 program (Peakal, Australian National University, Canberra, Australia).

Table 2. Primers used in the ISSR technique.

\begin{tabular}{|c|c|}
\hline Primer & Sequence ( $5^{\prime}$ to $\left.3^{\prime}\right)$ \\
\hline $\mathrm{CCA}$ & $\mathrm{DDB}(\mathrm{CCA})_{5}$ \\
\hline CGA & $\mathrm{DHB}(\mathrm{CGA})_{5}$ \\
\hline GT & $\operatorname{VHV}(\mathrm{GT})_{5} \mathrm{G}$ \\
\hline AG & $\mathrm{HBH}(\mathrm{AG})_{7} \mathrm{~A}$ \\
\hline $\mathrm{CT}$ & $\mathrm{DYD}(\mathrm{CT})_{7} \mathrm{C}$ \\
\hline TG & $\mathrm{HVH}(\mathrm{TG})_{7} \mathrm{~T}$ \\
\hline $\mathrm{CA}$ & $\operatorname{DBDA}(\mathrm{CA})_{7}$ \\
\hline $\mathrm{ACA}$ & $\mathrm{BDB}(\mathrm{ACA})_{5}$ \\
\hline
\end{tabular}

The following designations are used for the degenerate sites: $\mathrm{H}$ (A or $\mathrm{T}$ or $\mathrm{C}$ ); $\mathrm{B}(\mathrm{G}$ or $\mathrm{T}$ or $\mathrm{C}) ; \mathrm{V}(\mathrm{G}$ or $\mathrm{A}$ or $\mathrm{C})$ and $\mathrm{D}(\mathrm{G}$ or $\mathrm{A}$ or $\mathrm{T})$. 


\section{RESULTS AND DISCUSSION}

The analysis with the Nei-Li coefficient (Nei and Li, 1979) at a similarity level of 0.60 showed that the first group mainly included the gulupa materials from the municipalities Firabitoba and Ramiriquí. No grouping by species was observed since the other gulupa materials from the municipality Miraflores were distributed in other groups (Figure 1). Group II, at a similarity of 0.50 , was made up of eight materials, including granadilla, curuba red flower, gulupa and passion fruit, and was highly variable. Also, at a similarity of 0.50 , Group III mainly contained the gulupa species from Miraflores and the calabash species from Miraflores and Turmeque, in addition to the white and red flower curuba. Group IV had all the passion fruit materials from the municipality of Tunungua, the white and red flower curuba of Umbita and Turmeque and the granadilla of Tinjacá. At a similarity of 0.60 , Group V included the most passion fruit materials from different geographical origins (Miraflores, Briceño and Tunungua). Group VI had the most materials, especially gulupa and curuba from Turmequé, Sutamarchán and Tinjacá, at a similarity of 0.55 . Finally, Group VII contained the materials that presented a lower degree of similarity (0.40), 15 (granadilla), 64 (maracuyá) and 41 and 42 (gulupa) from Ramiriquí, Tunungua and Buenavista, probably because the origin was wild or spreading distribution.

In general, the clusters reflected the phenotypic variability observed in these species (Torres et al., 2019). The similarity rates were not so high since they are allogamous species, with sexual reproduction preferred, so there was manifest variability with no consistent formation of groups in terms of geographical origin or species, but there was lax distribution of the materials in terms of the evaluated municipalities, with inter- and intraspecific variability that can be used to obtain new planting materials. The lack of group structuring according to the geographical origin or species probably derive from the self-incompatibility found in most Passiflora species and the cross-pollination (Ocampo et al., 2017). The presence of exotic species such as gulupa or curuba also made a great contribution to the total genetic diversity observed in each group (Figure 2).

The gulupa (Passiflora edulis Sims f. edulis) is a neotropical species, known as purple passion fruit. In Colombia it is cultivated between 1800 and $2400 \mathrm{~m}$ a.s.l. and its fruit is considered promising, with high potential in the Colombian agricultural and export market. Its flavor, appearance, nutritional value, availability, accessibility and medicinal properties, in addition to its exotic connotation, make it a product in high demand in the international market (Checa et al., 2011;

Figure 1. Dendrogram for the 70 Passiflora spp. genotypes based on the Nei-Li (1978) similarity coefficient and calculated with eight ISSR markers with the UPGMA, SAHN and TREE of NTSYs-pc (version 2.02g, 1998) classification methods.

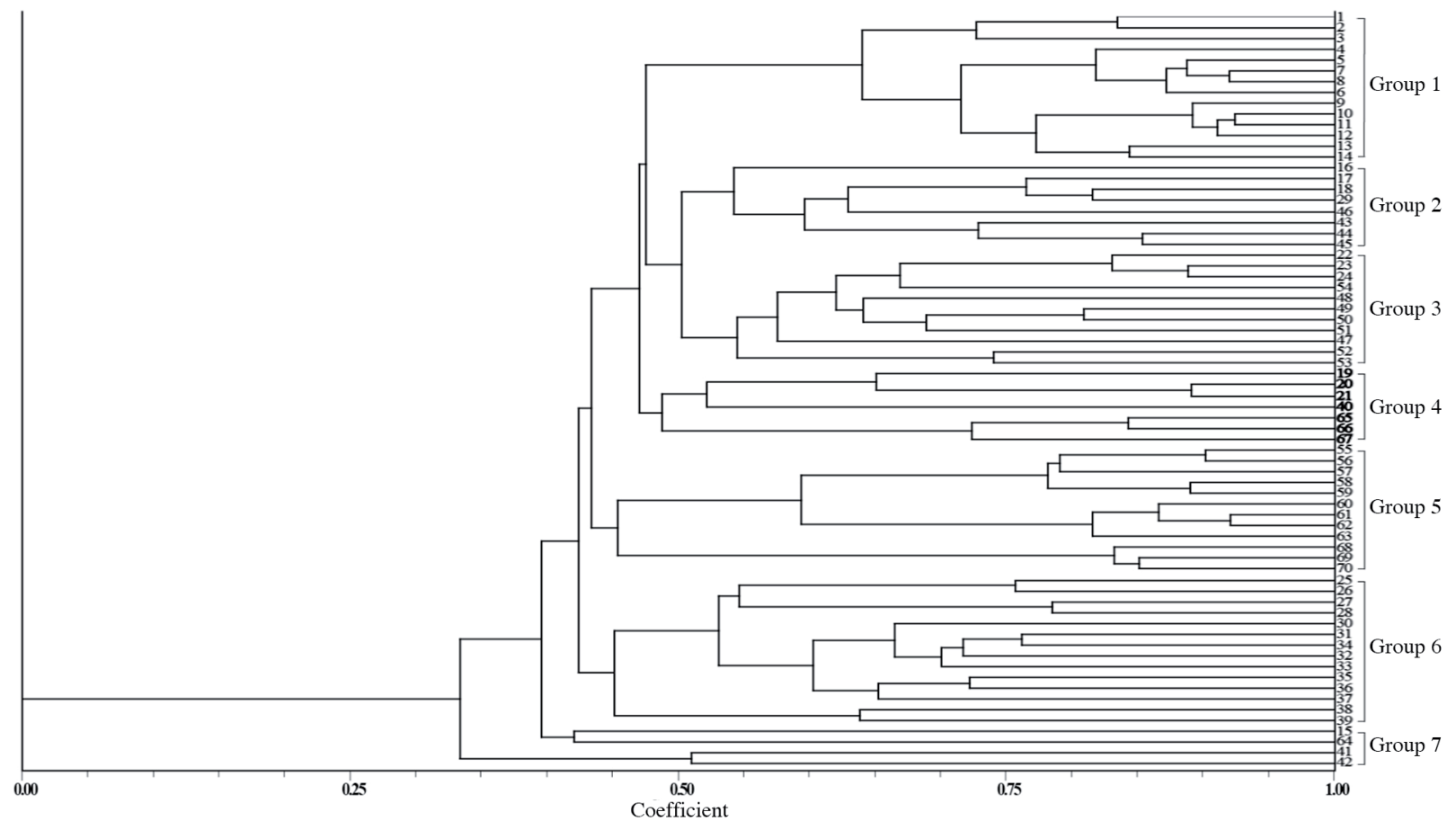


Figure 2. Amplification patterns generated by the ISSR TG in which inter and intraspecific variation in Passiflora material evaluated.

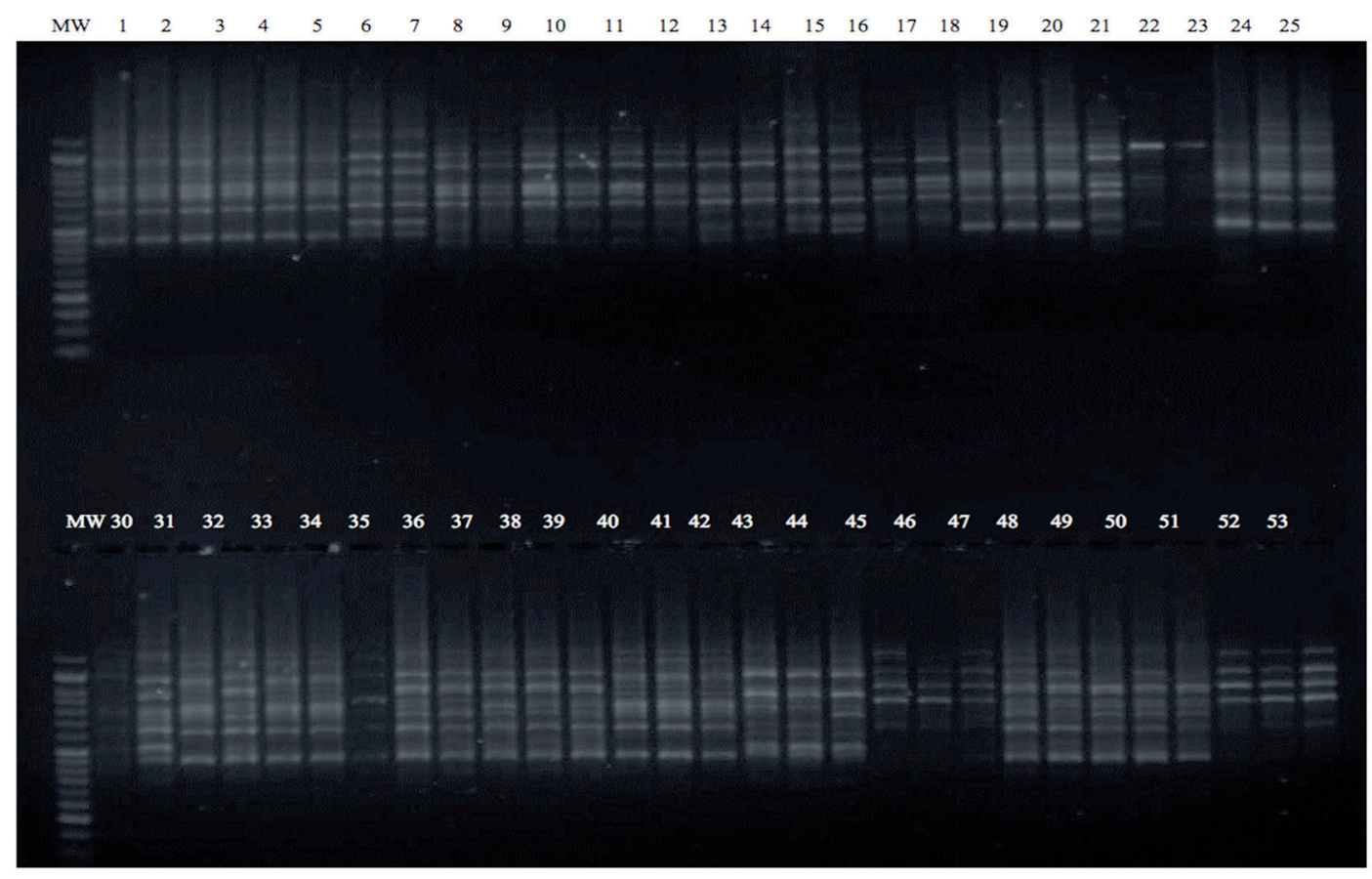

Meneses et al., 2019). On the other hand, curuba (P. tripartita var. mollissima) materials are characterized by a fruit tree native to the northern Andes, introduced to countries such as Chile, Mexico, New Zealand, Australia, and USA, classified as one of the best edible Passifloras spp. for its appetizing organoleptic characteristics and its high nutritional content. Additionally, it has nutraceutical importance given its high antioxidant potential (Meneses et al., 2019).

The coefficient of cofenetic correlation was $75 \%$, demonstrating a relationship between the genetic distances and the groups. Similar results were obtained by Batista et al. (2017) when evaluating genetic diversity in $P$. cincinnata accessions based on morphological descriptors and molecular markers and by Oliveira et al. (2019) when evaluating the genetic diversity of Passiflora spp. using ISSR and RAPD markers. Sousa et al. (2015) used ISSR markers in wild species of Passiflora spp. as a tool for the selection of taxa in the improvement of ornamentals and found that, despite a high coefficient of cofenetic correlation $(\mathrm{r}=0.94)$ that suggested fidelity in the representation of the dendrogram, some taxa were distributed without taxonomic support; therefore, the species were separated into different groups.

The average value of Nei-Li genetic diversity was 0.40 , consistent with that expected for cross-pollinated species and with the values observed in studies on genetic diversity in Passiflora (Santos et al., 2011; Oluoch et al., 2018; Oliveira et al., 2019; Vianna et al., 2019). Ocampo et al. (2017), when evaluating the diversity and genetic structure of $P$. edulis f. flavicarpa in Colombia with microsatellites, found an average genetic distance of 0.683 and that the structuring of the groups was not consolidated and could vary, just as in this study it was observed that the internal branches of the dendrogram were moderately compatible (bootstrap $\geq 50 \%$ ) and ratified the grouping between some materials of the same department. The relationship between individuals of the same species was low and did not present a geographical pattern according to the origin of each material. In most cases, this instability occurs when some individuals show intermediate similarity values compared to other groups when they are grouped and, therefore, are not assigned to a specific one and can belong to several compound branches (Oliveira et al., 2019).

The eight ISSR markers (Table 2) used to characterize the genetic diversity of Passiflora materials from the Department of Boyacá produced a total of 138 bands. The number of bands per primer varied from 10 for CA to 24 for GT, with molecular weights between 250 and $1320 \mathrm{~kb}$ (Table 3). The number of bands obtained in this study was adequate for estimating genetic parameters when compared to other studies on genetic diversity in Passiflora where these markers have been used (Sousa et al., 2015; Oliveira et al., 2019; Vianna et al., 2019). Considering the high rate of dinucleotide SSR describe in others studies for Passiflora spp. (Santos et al., 2011; Sousa et al., 2015) we chose the ISSR markers 
Table 3. Percentage of polymorphic loci and average expected heterozygosity (He) for the eight ISSRs evaluated in Passiflora materials.

\begin{tabular}{lccccc}
\hline Primer & $\begin{array}{c}\text { Number of } \\
\text { bands }\end{array}$ & $\begin{array}{c}\text { Polymorphic } \\
\text { loci } \%\end{array}$ & He & FST & $\begin{array}{c}\text { Standard } \\
\text { deviation }\end{array}$ \\
\hline ACA & 18 & 72 & 0.56 & 0.41 & 0.04 \\
AG & 20 & 90 & 0.58 & 0.21 & 0.01 \\
CA & 10 & 70 & 0.28 & 0.35 & 0.02 \\
CCA & 18 & 61 & 0.51 & 0.43 & 0.04 \\
CGA & 16 & 50 & 0.57 & 0.41 & 0.04 \\
CT & 14 & 71 & 0.38 & 0.38 & 0.02 \\
TG & 18 & 56 & 0.54 & 0.47 & 0.03 \\
GT & 24 & 79 & 0.48 & 0.30 & 0.02 \\
\hline Total & 138 & 75 & 0.56 & 0.16 & 0.01 \\
\hline
\end{tabular}

FST: Genetic differentiation coefficient.

to characterize the genetic diversity present in the evaluated materials. The percentage of polymorphic loci for the eight ISSR primers was between $56 \%$ (TG) and $90 \%$ (AG), with an expected average heterozygosity of 0.17 to 0.38 for the CGA and AG primers, respectively (Table 3). The first TG showed a greater genetic differentiation between the materials, with a genetic differentiation coefficient (FST) of 0.47 , which means that it can be useful for studies on genetic diversity in Passiflora (Figure 2).

For the total population, the percentage of polymorphic loci and the expected average heterozygosity (He) were $75.4 \%$ and 0.56 , respectively (Table 3), because of the genetic nature of the materials, the type of marker, and the genome coverage, among others. The FST obtained when evaluating the Passiflora materials with the eight ISSR markers was 0.16, with a standard deviation of 0.01 (Table 3). According to Wright (1978), values greater than 0.25 show great genetic differentiation, so there was not a population genetic structure in the evaluated materials.

The AMOVA showed that $64 \%$ of the variation observed in the evaluated Passiflora materials was explained by the component within the groups, and $36 \%$ was explained by the differentiation between the groups, so it is necessary to consider subdivision levels and hierarchy greater than those contemplated in this study, in addition to the high levels of variation at the intraspecific level, which should be used for management and conservation strategies of this plant genetic resource (Table 4), which has also been reported in other genetic diversity studies on Passiflora using this marker (Ocampo et al., 2017; Oluoch et al., 2018; Fonseca-Trujillo et al., 2019). In interspecific analyses, a higher polymorphism rate in combination with a higher average number of bands amplified per primer is indicative of high genetic diversity (CerqueiraSilva et al., 2012). However, there was also high intraspecific genetic diversity among the evaluated Passiflora materials.

In studies on genetic diversity in Passiflora, it has been found that ISSR markers are highly polymorphic and informative (Batista et al., 2017; Oliveira et al., 2019; Vianna et al., 2019); in addition, heterozygosity values greater than those found in this study have been reported by Lougon et al. (2014) when evaluating the genetic diversity in the Passiflora genus with SSR markers, finding an average heterozygosity of $\mathrm{He}=0.57$. These values show broad genetic variability in the Passiflora genus. Similar values were found by Cerqueira-Silva et al. (2012), who evaluated P. cincinnata accessions and obtained $\mathrm{He}=0.51$, and Cazé et al. (2012), who used seven microsatellite loci to study the genetic structure.

In Colombia, genetic diversity studies on Passiflora, such as those carried out by Fonseca-Trujillo et al. (2009), who used ISSR markers, have characterized the cultivated gulupa materials collected in the Departments of Boyacá, Cundinamarca and Huila, finding that these molecular markers were efficient at detecting polymorphisms in this species (89\%), evidencing broad genetic diversity that is distributed in the areas where gulupa is grown. The gulupa materials evaluated in this study showed high genetic diversity, probably because of the propagation method, origin and short time of establishment of these crops in this country.

Table 4. Molecular variance analysis for groups formed with the eight ISSR markers.

\begin{tabular}{lccccc}
\hline Source & DF & SS & MS & SV & $\%$ \\
\hline Between group & 10 & 677.33 & 67.73 & 8.62 & 36 \\
Within group & 59 & 909.15 & 15.41 & 15.40 & 64 \\
\hline Total & 69 & 1586.48 & & 24.05 \\
\hline
\end{tabular}

DF: Degrees of freedom; SS: sum of squares; MS: middle square; SV: standard variation. 
Ocampo et al. (2017), in the study on the diversity and genetic structure of passion fruits in Colombia using microsatellite markers, found that six microsatellite loci amplified a total of 58 alleles, including nine unique and 31 rare ones. The diversity indices showed a polymorphic information content (PIC) of 0.74 , an average observed heterozygosity of Ho = 0.52 and an expected $\mathrm{He}=0.78$, evidencing a poor geographical structuring and high diversity in the accessions, which could be explained by the allogamy and the constant exchange of seeds among farmers.

Studies on collection and morphoagronomic characterizations in Passiflora in Colombia have demonstrated the wide phenotypic variation that exists in cultivated and wild materials, as reported by Checa et al. (2011), who collected and morphoagronomically characterized 91 materials of the subgenus Tacsonia and eight materials of the subgenus manicata, finding that the characteristics that contributed most to the phenotypic variation were associated with the fruit and the phytosanitary state of the materials. Similar results were obtained by Ocampo et al. (2013) in the exploration of the genetic variability of passion fruits as a basis for a breeding program in Colombia, in which quality parameters were taken into account and eight elite accessions from Caldas, Valle del Cauca and Antioquia were identified. The classification analysis showed high variability, with little structuring by geographical origin. Galeano et al. (2018), when characterizing the production and physicochemical variables of 60 passion fruit accessions conserved at the Corporación Colombiana de Investigación Agropecuaria (AGROSAVIA), obtained results from the grouping and principal components that showed broad genetic diversity in the entire collection without any population substructure, as seen in this study 30 promising accessions were identified as parental for the first cycle of recurrent selection. These results are the basis for initiating a process of genetic improvement from the superior genotypes of the elite accessions identified. However, these materials have not been identified for the Department of Boyacá, which is why this study, together with morphoagronomic and quality data, is vital to starting a breeding program that leads to new and better materials.

In this study, it was found that there is high genetic diversity among the Passiflora materials grown in the Department of Boyacá. Most of these materials showed different genetic backgrounds and were probably derived from a number of introductions from Hawaii (USA) and Brazil that started in the 1960s, along with the flow of genes through seed exchanges between farmers with different geographical origins and the allogamy of these species, resulting in an increase in allele distribution between different accessions; as well as its way of reproduction, since in general terms the species belonging to the genus Passiflora are spread asexually through grafts, cuttings and tissue culture in vitro; and sexual route from the seed, however the latter is the most used method in most of these species in Colombia (Faleiro et al., 2019). This is consistent with the results found in others, such as P. peruviana (Morillo et al., 2018), who argued that genetic polymorphism can be associated with the allogamous nature of the species and the exchange of seeds between producers, which tend to favor the conservation of a high percentage of heterozygous genotypes.

Knowledge on inter- and intraspecific genetic diversity provides useful information for effective conservation, management of plant genetic resources and breeding programs (Oluoch et al., 2018). Variability between genotypes is important for breeders in the selection of high-yield varieties, so the existence of variability among individuals is a prerequisite for the production of new varieties aimed at improving crop productivity, with the ability to resist the impacts of biotic or abiotic stress (Oliveira et al., 2019).

\section{CONCLUSIONS}

The ISSR markers allowed to determine the existence of an important genetic variability in the Passiflora spp. material collected in the department of Boyacá, which is presented mainly at the intraspecific level, which suggests higher levels of hierarchy and subdivision than those considered in this study.

There is a genetic potential in the evaluated material that must be exploited in conservation and plant breeding strategies of Passiflora spp. in the main producing municipalities of the department of Boyacá.

\section{ACKNOWLEDGEMENTS}

The authors express their sincere thanks to the Passiflora producers in the department of Boyacá, the research group Competitividad, Innovación y Desarrollo Empresarial (CIDE) and the Maestría en Ciencias Biológicas, Universidad Pedagógica y Tecnológica de Colombia for their financial support of this research. 


\section{REFERENCES}

Agronet. 2019. Área, producción y rendimiento de Passifloras en Colombia. Agronet, Bogotá, Colombia. Available at https://www .agronet.gov.co/estadistica/Paginas/home.aspx?cod=1 (accessed December 2019).

Araya, S., Martins, A.M., Junqueira, N., Costa, A.M., Faleiro, F.G., and Ferreira, M.E. 2017. Microsatellite marker development by partial sequencing of the sour passion fruit genome (Passiflora edulis Sims). BMC Genomics 18:549-567. doi:10.1186/s12864-017-3881-5.

Batista, T., Martins, L., Dos Santos, R., Da Silva, M., and Oliveira, J. 2017. Genetic diversity in accessions of Passiflora cincinnata Mast. based on morphoagronomic descriptors and molecular markers. Revista Caatinga 30:68-77. doi:10.1590/1983-21252017v30n108rc.

Bernal, N., Ocampo-Pérez, J., y Hernández-Fernández, J. 2014. Caracterización y análisis de la variabilidad genética de la granadilla (Passiflora ligularis Juss.) en Colombia empleando marcadores microsatélites. Revista Brasileira de Fruticultura 36:598-611. doi:10.1590/0100-2945-251/13.

Cazé, A.L.R., Kriedt, R.A., Beheregaray, L.B., Bonatto, S.L., and Freitas L.B. 2012. Isolation and characterization of microsatellite markers for Passiflora contractu. International Journal of Molecular Sciences 13:11343-11348.

Cerqueira-Silva, C.B.M., Santos, E.S.L., Souza, A.M., Mori, G.M., Oliveira, E.J., Correa, R.X., et al. 2012. Development and characterization of microsatellite markers for the wild South American Passiflora cincinnata (Passifloraceae). American Journal of Botany 99:170-172. doi:10.3732/ajb.1100477.

Checa, O., Rosero, E., y Eraso, I. 2011. Colección y caracterización morfoagronómica del subgénero Tacsonia en la zona andina del departamento de Nariño, Colombia. Revista Facultad Nacional de Agronomía, Medellín 64:5893-5907.

Dellaporta, S., Wood, J., and Hicks, J. 1983. A plant DNA minipreparation: Version II. Plant Molecular Biology Reporter 1:19-21.

Faleiro, F.G., Junqueira, N.T.V., Junghans, T.G., Jesus, O.N., Miranda, D., and Otoni, W.C. 2019. Advances in passion fruit (Passiflora spp.) propagation. Revista Brasileira de Fruticultura, Jaboticabal 41:2-17. http://dx.doi.org/10.1590/0100-29452019155.

Fonseca-Trujillo, N., Márquez, M., Moreno, J., Terán, W., y Schuler, I. 2009. Caracterización molecular de materiales cultivados de gulupa (Passiflora edulis f. edulis). Universitas Scientiarum 14:135-140. doi:10.11144/javeriana.SC14-2-3.cmdm.

Galeano, C., Cerón, I., and Arango, V. 2018. Agronomic evaluation of a Colombian passion fruit (Passiflora edulis Sims) germplasm collection. Agronomy Research 16:1-12. doi:10.15159/ar.18.190.

Gramazio, P., Plesa, I., Truta, A., Sestras, A., Vilanova, S., Plazas, M., et al. 2018. High informative SSR genotyping reveals large genetic diversity and limited differentiation in European larch (Larix decidua) populations from Romania. Turkish Journal of Agriculture and Forestry 422:165-175. doi:10.3906/tar-1801-4.1.

Konta, E.M., Almeida, M.R.., Amaral, M.R., Darin, J.D.C., Rosso, V.V., Mercadante, A.Z., et al. 2014. Evaluation of the antihypertensive properties of yellow passion fruit pulp (Passiflora edulis Sims f. flavicarpa Deg.) in spontaneously hypertensive rats. Phytotherapy Research 28:28-32. doi.org/10.1002/ptr.4949.

Lougon, C., Vianna, A., Azevedo, E., De Oliveira, J., Nonato, R., and De Oliveira, J. 2014. Genetic variability assessment in the genus Passiflora by SSR markers. Chilean Journal of Agricultural Research 74:355-360. doi:10.4067/S0718-58392014000300015.

Malacrida, C.R., and Neuza, J. 2012. Yellow passion fruit seed oil (Passiflora edulis f. flavicarpa): physical and chemical characteristics. Brazilian Archives of Biology Technology 55:127-134. doi.org/10.1590/S1516-89132012000100016.

Meneses, M., Nixon, A., Herrera, E., y Tarazona, M. 2019. Caracterización y estabilidad de un extracto rico en antocianinas a partir del epicarpio de gulupa (Passiflora eduli f. edulis Sims). Revista Colombiana de Química 48:1-15. doi:10.15446/rev.colomb.quim.v48n2.76682.

Morillo, A.C., González, J., y Morillo, Y. 2018. Caracterización de la diversidad genética de uchuva (Physalis peruviana L.). Biotecnología en el Sector Agropecuario y Agroindustrial 16:26-33. doi:10.18684/bsaa.v16n1.631.

Nei, M., and Li, W. 1979. Mathematical model for studying genetic variation in terms of restriction endonucleasa. Proceedings of the National Academy of Sciences of the United States of America 76:5269-5273.

Ocampo, J., Acosta, N., and Hernández, J. 2017. Variability and genetic structure of yellow passion fruit (Passiflora edulis f. flavicarpa Degener) in Colombia using microsatellite DNA markers. Agronomía Colombia 35:135149. doi:10.15446/agron.colomb.v35n2.59973.

Ocampo, J., Urrea, R., Wyckhuys, K., y Salazar, M. 2013. Exploración de la variabilidad genética del maracuyá (Passiflora edulis f.flavicarpa Degener) como base para un programa de fitomejoramiento en Colombia. Acta Agronómica 62:352-360.

Oliveira, J., Gelape, F., Vilela, N., Da Fonseca, G., and Araya, S. 2019. Genetic variability of Passiflora spp. base on ISSR and RAPD. Asian Journal of Science and Technology 10:9375-9378.

Oluoch, P., Nyaboga, E., and Bargul, J. 2018. Analysis of genetic diversity of passion fruit (Passiflora edulis Sims) genotypes grown in Kenya by sequence-related amplified polymorphism (SRAP) markers. Annals of Agrarian Science 16:367-375. doi:10.1016/j.aasci.2018.08.003. 
Pereira, D.A., Correa, R.X., and Oliveira, A.C. 2015. Molecular genetic diversity and differentiation of populations of "somnus" passion fruit trees (Passiflora setacea DC): Implications for conservation and pre-breeding. Biochemical Systematics and Ecology 59:12-21. doi.org/10.1016/j.bse.2014.12.020.

Santos, L.F., Oliveira, E.J., Santos, A.S., Carvalho, F.M., Costa, J.L., and Padua, J.G. 2011. ISSR markers as a tool for the assessment of genetic diversity in Passiflora. Biochemical Genetics 49:540-554. doi:10.1007/s10528-011-9429-5.

Sousa, A., Souza, M., Melo, C., and Sodré, G. 2015. ISSR markers in wild species of Passiflora L. (Passifloraceae) as a tool for taxon selection in ornamental breeding. Genetics and Molecular Research 14:18534-18545. doi:10.4238/2015.

Torres, G.X., Viana, A.P., Vieira, H.D., Rodrigues, D.L., and dos Santos, V.O. 2019. Contribution of seed traits to the genetic diversity of a segregating population of Passiflora spp. Chilean Journal of Agricultural Research 79:288-295. doi:10.4067/S0718-58392019000200288.

Vianna, L., Pereira, T., Santos, E., Vianna, A., Pereira, M., Ramos, H., et al. 2019. ISSR and SSR markers for determining genetic relationships among three wild species of Passiflora. Genetic and Molecular Research 18:1-10. doi.org/10.4238/gmr18040.

Vieira, A., Peixoto, J., Gelape, F., Souza, M., and Carvalho, M. 2019. Molecular characterization and genetic diversity of yellow passion fruit based on RAPD markers. Journal of Agricultural Science 11:575-580. doi:10.5539/jas.v11n3p575.

Wright, S. 1978. Evolution and the genetics of populations, variability within and among natural populations. University of Chicago Press, Chicago, Illinois, USA. 